\title{
A Water Management System for Reducing Non-Revenue Water in Potable Water Lines: The Case of Sri Lanka
}

\author{
B.A.K.S. Perera, H. Mallawaarachchi, K.S. Jayasanka and \\ R.R.P.N. Rathnayake
}

\begin{abstract}
In every country, a significant quantity of water is lost from the distribution system before it could be billed. This water named as non-revenue water (NRW) reduces considerably the revenue earned by the utility by selling treated water. Thus, this research aimed to propose a cost effective management system for the non-revenue water lost from the water distribution system in Sri Lanka. The research used a quantitative approach. A questionnaire survey was carried out to identify the severity of each type of water loss. The data collected were analysed to categorize under four main groups the causes that produce non-revenue water in the distribution systems: distribution line leaks, administrative errors, illegal water usage and free water supply. Finally, a cost effective management model was developed outlining the strategies that could be adopted to prevent the different types of water losses. The cost effectiveness of investing in non-revenue water reduction in the water distribution system in Sri Lanka was determined by referring to archival records. The cost effective model developed would be useful in long-term planning to significantly reduce the water lost from the distribution systems in the country.
\end{abstract}

Keywords: $\quad$ Non-Revenue Water, Water Losses, Water Management, Cost Effectiveness

\section{Introduction}

Among the basic needs of human beings, the demand for water is gradually increasing and is found to be one of the most essential human needs [13]. The general willingness of the authorities to fulfil all requirements of the growing world population using the precious and limited resources available has resulted in a scarcity of these resources including water. Potable water is supplied for optimizing water consumption. Potable water is water that has been treated to make it suitable for drinking [31]. During its transmission and distribution to consumers, it can get wasted due to several unavoidable reasons including careless administrative mistakes. The water that is lost in this manner is called non-revenue water (NRW). The distribution of potable water from their sources becomes more important when the houses to which the water is supplied are scattered over a large area [17]. As stated by Mutikanga, Sharma, and Vairavamoorthy in [17], non-revenue water is an issue common to all developing countries especially to Asian countries. In Asian cities, on average, only about $35 \%$ of the water that is fed into the distribution system is billed [32].

In Sri Lanka, which is a developing country in Asia, a significant percentage of water is lost during its distribution incurring a financial loss to the National Water Supply and Drainage Board (NWS\&DB) of the country [34]. At the NWS\&DB, there is a separate section for water loss management and reduction of non-revenue water [29]. Chandrathilaka and Fernando in [30] have mentioned that because of lack of proper technology, Sri Lanka still depends on conventional systems for reducing the water wasted while being distributed.

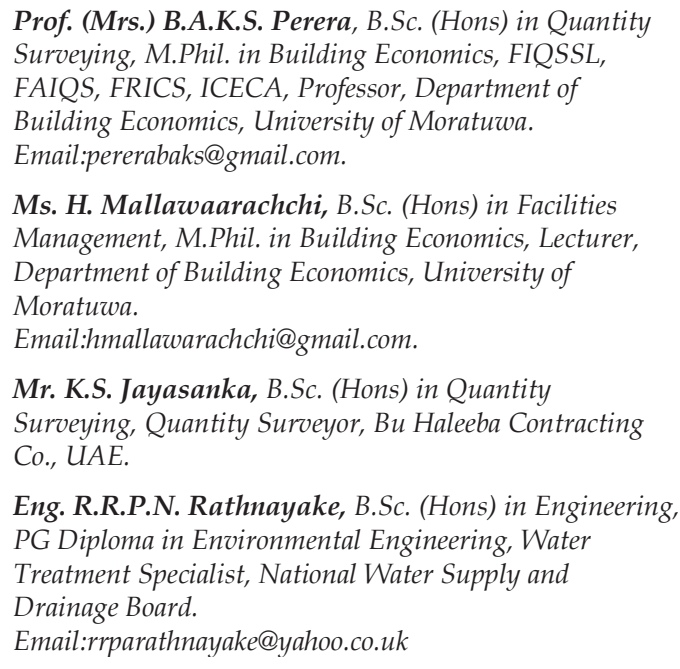

Prof. (Mrs.) B.A.K.S. Perera, B.Sc. (Hons) in Quantity Surveying, M.Phil. in Building Economics, FIQSSL, FAIQS, FRICS, ICECA, Professor, Department of Building Economics, University of Moratuwa. Email:pererabaks@gmail.com.

Ms. H. Mallawaarachchi, B.Sc. (Hons) in Facilities Management, M.Phil. in Building Economics, Lecturer, Department of Building Economics, University of Moratuwa.

Email:hmallawarachchi@gmail.com.

Mr. K.S. Jayasanka, B.Sc. (Hons) in Quantity Surveying, Quantity Surveyor, Bu Haleeba Contracting Co., UAE.

Eng. R.R.P.N. Rathnayake, B.Sc. (Hons) in Engineering, PG Diploma in Environmental Engineering, Water Treatment Specialist, National Water Supply and Drainage Board.

Email:rrparathnayake@yahoo.co.uk 
However, despite the many precautions taken, it is seen that water is still being lost during its distribution. There have been many research studies conducted on the types of water losses, how water gets wasted due to leaks during daily activities [9], volume of water actually used as a percentage of the volume of the treated water [22] and the volume of nonrevenue water as a percentage of the total volume of treated water supplied [8]. There have been several studies to identify ways of saving water during day to day activities, ways of managing the available water resource in a sustainable way etc. However, the severity of water losses in the distribution systems, cost of implementing NRW reduction activities as well as the revenue that can be earned by adopting those methods and their degree of applicability in Sri Lanka have so far not been studied. Therefore, this research focused on preparing a cost effective water loss management system to minimize the volume of non-revenue water in the potable water distribution networks in Sri Lanka.

The objectives of this research were (1) to identify the water losses common in distribution pipes and their severity, (2) to do an economic analysis of active leakage control programs and reduce illegal water connections and (3) to do an economic analysis of reducing administrative losses.

\section{Literature Review}

\subsection{Non-Revenue Water (NRW) in Developing Countries}

The database maintained by the World Bank on water utility performance, "The International Benchmarking Network for Water and Sanitation Utilities (IBNET)," includes data from more than 900 utilities operating in 44 developing countries. According to this database, the average percentage of NRW in the countries considered is around 35\%. NRW in Colombo, Sri Lanka has been $46 \%$ in 2016. A high NRW level means that a large amount of water is being lost from the distribution system through leaks. The amount of NRW is the most accurate indicator of the income lost by the utility due to water losses. Most of the utilities in developing countries are interested in only earning revenue. They maintain their systems only to provide water and the increased expenditure incurred as a result of NRW is met by increasing water tariff and not by introducing leak controlling programs ([3],[4]).
Although statistical data pertaining to water usage in major cities of the developed countries are available for analysis, no such data are available for most of the major cities in developing countries as records of NRW are not properly maintained in those countries due to non-availability of domestic / bulk flow meters and continuous monitoring developing countries in Asia is around 35\% (Figure 1).

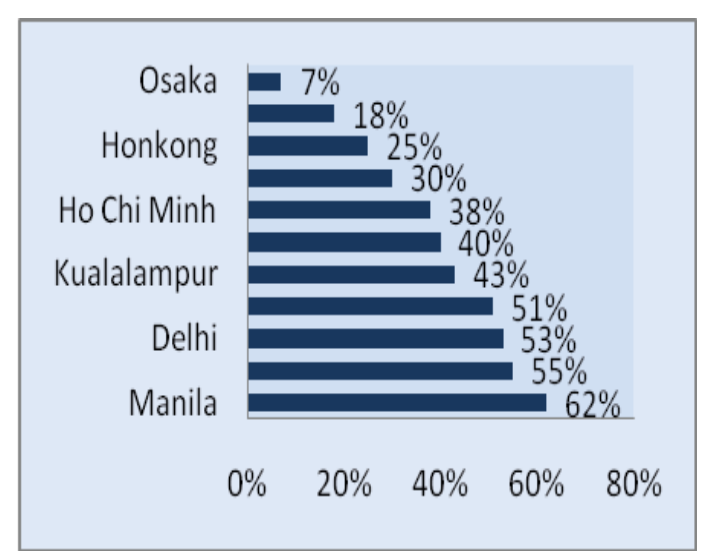

Figure 1 - NRW in developing countries (Asian Development Bank Annual Reports, 2004 as cited in [18])

More attention therefore has to be paid to reducing the amount of non-revenue water in these countries as the high cost of chemicals and energy, and high administrative, capital and maintenance costs make the production of treated water quite expensive. A study by [31] has categorized water losses as indicated below to enable the calculation of NRW.

- Apparent losses -Non-physical losses relating to the amount of water that does not generate revenue though it is not wasted or lost [12]. This quantity of water will not be taken into account when computing the revenue.

- Real losses- Physical losses that can be seen and physically identified [12]. IWA (2010) cited in [25] describes real losses as the amount of water measured as Unaccounted for Water (UFW). The difference between net production and end consumption is considered as real losses that occur within the distribution system.

\section{Non-Revenue Water Management and} the Need for it

Water which is a source of revenue for a utility is a resource that needs conservation to ensure its sustainability [32]. Furthermore, water 
Table 1- Water loss management techniques

\begin{tabular}{|c|c|c|c|c|c|c|c|c|c|c|c|c|c|c|}
\hline $\begin{array}{c}\text { Water loss } \\
\text { management }\end{array}$ & \multicolumn{14}{|c|}{ Source of reference } \\
\hline & [6] & [11] & [14] & [10] & [26] & [12] & [4] & [18] & [15] & [31] & [13] & [30] & [19] & [33] \\
\hline Water audit & $x$ & $x$ & & & & $x$ & & & & & & & & \\
\hline $\begin{array}{l}\text { Leakage monitoring } \\
\text { and control methods }\end{array}$ & & & & $x$ & $x$ & & & & & & & & & \\
\hline $\begin{array}{l}\text { Routine or regular } \\
\text { sounding }\end{array}$ & & & & & & & $x$ & & & & & & & \\
\hline Meter management & & & & & & & & $x$ & $x$ & & & & & \\
\hline District meter areas & & & & & & & & & & & & & $x$ & $x$ \\
\hline Pressure management & $x$ & & $x$ & & & & & & & & & & & \\
\hline $\begin{array}{l}\text { Deteriorated smaller } \\
\text { pipe line replacement }\end{array}$ & & & & & & & & & & $x$ & $x$ & & & \\
\hline $\begin{array}{l}\text { Rehabilitation of } \\
\text { distribution networks }\end{array}$ & & & & & & & & & & & $x$ & & & \\
\hline Part to whole system & & & & & & & & & & & & & $x$ & \\
\hline $\begin{array}{l}\text { Asset management } \\
\text { and ownership } \\
\text { concept }\end{array}$ & & & & & & & & & & & & $x$ & & \\
\hline
\end{tabular}

would become a critical issue in the twentyfirst century in spite of the increasing awareness around the world on the possible shortage of water in the future.

Therefore, water needs to be treated as a valuable resource and saved with high priority without letting it go waste. Saving of water that has been treated up to potable level is very important. For the utilities, reducing the amount of non-revenue water has become a major task. The key for improved water reduction is the identification of the most appropriate technique for non-revenue water management [9].

Developed countries through the use of appropriate techniques keep their average NRW levels below 15\% [11]. There are several water loss management techniques available globally. Ten of these major techniques identified from the literature are presented in Table 1.

After identifying the types of non-revenue water from the literature, the water loss management systems available were studied. It was revealed from the literature review that there is a control on the NRW levels in developed countries. In developing countries, it is common to find high levels of NRW with the average NRW level standing at around 35\%. These high NRW levels in developing countries have to be controlled through suitable management strategies. The strategies used in developed countries may not be suitable for developing countries due to the differences in their economic, financial, political and environmental conditions.

The novelty of this research therefore is in the identification of strategies that will be effective in controlling the level of NRW in Sri Lanka. The strategies identified can be used to control the high NRW levels of other developing countries as well.

\section{Research Methodology}

This research comprised of two stages. During the first stage, an exploratory literature review was conducted and during the second stage, a set of preliminary interviews and a questionnaire survey were conducted. The extensive literature review was on the types of non-revenue water and the strategies used for their management. However, all the information collected was related only to other countries. They were validated during Stage 2 of the study to verify their applicability to Sri Lanka by using five face to face semi-structured interviews conducted with experts working in the water sector. The profiles of the interviewees are shown in Table 2. The outcome of the interviews was used to develop the questionnaire used in the questionnaire survey. Gliem and Kowalski in [27] have justified this approach as it takes the form of an exploratory and rigorous examination of reallife contexts with the interviewees getting the opportunity to relate literature findings to their own experiences. 
Table 2 - Profile of interviewees

\begin{tabular}{|l|l|l|l|l|l|}
\hline \multicolumn{1}{|c|}{ Details } & Interviewee A & Interviewee B & Interviewee C & Interviewee D & Interviewee E \\
\hline Profession & $\begin{array}{l}\text { Chartered Civil } \\
\text { Engineer }\end{array}$ & $\begin{array}{l}\text { Chartered Civil } \\
\text { Engineer }\end{array}$ & $\begin{array}{l}\text { Chartered Civil } \\
\text { Engineer }\end{array}$ & $\begin{array}{l}\text { Chartered Civil } \\
\text { Engineer }\end{array}$ & $\begin{array}{l}\text { Chartered Civil } \\
\text { Engineer }\end{array}$ \\
\hline Designation & $\begin{array}{l}\text { Additional } \\
\text { General } \\
\text { Manager }\end{array}$ & $\begin{array}{l}\text { Assistant } \\
\text { General } \\
\text { Manager }\end{array}$ & $\begin{array}{l}\text { Deputy General } \\
\text { Manager }\end{array}$ & Project Manager & Chief Engineer \\
\hline Experience & 30 years & 25 years & 25 years & 27 years & 25 years \\
\hline
\end{tabular}

Table 3 - Questionnaire distribution and response rate

\begin{tabular}{|l|l|c|c|c|}
\hline \multicolumn{1}{|c|}{ Designation } & \multicolumn{1}{|c|}{ Profession } & $\begin{array}{c}\text { Number of } \\
\text { questionnaires } \\
\text { distributed }\end{array}$ & $\begin{array}{c}\text { Number of } \\
\text { questionnaires } \\
\text { returned }\end{array}$ & $\begin{array}{c}\text { Response } \\
\text { rate }\end{array}$ \\
\hline Project Engineers & Chartered Engineer & 30 & 8 & $27 \%$ \\
\hline Assistant General Manager & Chartered Engineer & 20 & 10 & $50 \%$ \\
\hline Chief Engineer & Chartered Engineer & 30 & 12 & $40 \%$ \\
\hline Chief Quantity Surveyors & $\begin{array}{l}\text { Chartered Quantity } \\
\text { Surveyor }\end{array}$ & 20 & 10 & $50 \%$ \\
\hline Total & & $\mathbf{1 0 0}$ & $\mathbf{4 0}$ & $\mathbf{4 0 \%}$ \\
\hline
\end{tabular}

Feather-stitch (1991 and 2002 cited [2]) notes that the reliability and validly of the results of a research will be more objective and stronger when quantitative methods are used. According to [21], reliability is not of relevance in qualitative research as it is required only in measurements. Therefore, quantitative approach was identified as the most suitable research approach for this study. The details of the questionnaire distribution and the corresponding response rates are summarised in Table 3.

In a questionnaire survey, there is a standardized set of questions beginning with the words who, what, where, how much and how many and the questions generally receive good answers [1]. Thus, it was decided to conduct a detailed questionnaire survey to identify the locations of possible water leaks and their volumes. The method known as severity index (Equations (1) and (2)) which has been being widely used for severity calculations in several previous studies ([18], [7]; [14]; [23]) was used in this study too to identify the critical water losses in distribution pipes.

$$
S_{j}^{i}=\alpha_{j}^{i} \beta_{j}^{i}
$$

$\mathrm{WLS}=\frac{\sum_{j=1}^{n} S_{j}^{i}}{n}$ where $\mathrm{n}=$ number of responses; $\mathrm{S}_{j}{ }_{j}=$ evaluation of the severity of water losses by $\mathrm{j}^{\text {th }}$ respondent; $\alpha=$ evaluation of frequency level water loss occurrence by $j^{\text {th }}$ respondent; $\beta=$ evaluation of the magnitude of water loss occurrence from the $\mathrm{i}^{\text {th }}$ factor by $\mathrm{j}^{\text {th }}$ respondent; and WLS=Water loss Severity Index for the $\mathrm{i}^{\text {th }}$ risk factor. The mean weighted rating (MR) which has also been widely used in the previous studies ([15], [18]; [33]) was calculated as given below.

$$
M R=\frac{\sum w}{n}
$$

where MR=Mean Rating of a particular factor; $\mathrm{w}=$ Weighting given to each factor by the respondents, and $\mathrm{n}=$ Total number of respondents.

The mean weighted average was calculated separately for the mean ratings of the frequency of occurrence of water loss (MR-F) and the mean ratings for the magnitude of water loss (WR-M). Cronbach's Alpha which measures the consistency among individual items in a scale ([5], [27]; [14]; [26]; [24]) was used to identify the consistency of the data set. According to [28], Cronbach's Alpha is a measure of how well each individual item in a scale correlates with the sum of the remaining items. Since Alpha was above 0.7 for the data set, the data were considered as reliable [5].

The standardized Cronbach's $\alpha$ is defined as follows:

$$
\alpha=\frac{N \cdot \bar{c}}{(\bar{v}+(N-1) \cdot \bar{c})}
$$


Table 4 - Severity of water losses

\begin{tabular}{|c|c|c|c|c|c|}
\hline No. & Cause of water losses & $\begin{array}{l}\text { Frequency } \\
\text { (MR-F) }\end{array}$ & $\begin{array}{l}\text { Magnitude } \\
\text { (MR-M) }\end{array}$ & $\begin{array}{l}\text { Water Loss } \\
\text { Severity } \\
\text { (WLS) }\end{array}$ & Rank \\
\hline R.07 & By passing of water connections & 2.32 & 2.74 & 6.36 & 1 \\
\hline R.03 & Deteriorated pipe lines & 3.11 & 1.89 & 5.88 & 2 \\
\hline R.05 & $\begin{array}{l}\text { Deformation of pipes due to hard roots of } \\
\text { trees }\end{array}$ & 1.95 & 2.68 & 5.23 & 3 \\
\hline R.02 & Poor quality of the materials used & 2.42 & 2.32 & 5.16 & 4 \\
\hline R.01 & Poor workmanship & 2.45 & 1.95 & 4.78 & 5 \\
\hline R.06 & $\begin{array}{l}\text { Damages caused by unforeseen } \\
\text { excavations }\end{array}$ & 3.55 & 1.29 & 4.58 & 6 \\
\hline R.08 & Poor meter management & 2.24 & 1.84 & 4.12 & 7 \\
\hline R.04 & Leaks due to soil settlements & 1.97 & 1.92 & 3.78 & 8 \\
\hline R.09 & Purposely damaged distribution lines & 1.79 & 2.08 & 2.29 & 9 \\
\hline
\end{tabular}

where $\mathrm{N}$ is the number of components, $\bar{v}$ equals the average variance and $\bar{c}$ is the average of all co-variances between the components.

The documents available with the NWS\&DB were referred to (annual reports and research reports produced by NRW section), to obtain resource data and cost data needed for the NRW reduction program. Each method was evaluated against its costs and benefits. The findings of the data analysis were used to develop a cost effective NRW management model.

\section{Results and Discussion}

The findings of the data analysis are discussed under the following sub headings:

i. Severity of the water losses in the distribution systems

ii. Economic analysis of active leakage control programs

iii. Economic analysis of reducing illegal water connections

iv. Economic analysis of reducing administrative losses

v. Cost effective NRW management model

\subsection{Severity of the Water Losses in the Distribution Systems}

Towards calculating the severity of the water losses in the distribution systems, the probability and magnitude of each identified factor were first determined. The water losses identified were evaluated to determine the most common water loss/ water loss with the highest frequency of occurrence (MR-F). After identifying the types of water losses which are caused by leaks in the distribution pipes, the magnitude (MR-M) of each type of leak was calculated
Mean weighted rating was used to calculate the frequency and the magnitude of the water losses identified. The water loss severity (WLS) of each factor was calculated thereafter based on the frequency and the magnitude of the leaks in the distribution pipes. Table 4 summarizes the calculations pertaining to the severity of each factor along with their rankings.

From Table 4, it can be seen that the magnitude of the by passing of water connections has a mean rating of 2.74 and its frequency of occurrence has a mean rating of 2.32 . Deteriorated pipe lines was the second most severe factor with water loss severity, frequency of occurrence and the magnitude of the leak standing at 5.8, 3.11 and 1.89 respectively, which indicate that the frequency of occurrence is very high even though the magnitude of the leak is not that high. Deformation of pipes due to hard roots of trees was third in severity (WLS $=5.23$ ). Poor quality of the materials used, poor workmanship, and damages caused by unforeseen excavations were ranked fourth, fifth and sixth respectively with their mean ratings of severity standing at $5.16,4.78$ and 4.58 respectively.

Poor meter management (WLS=4.12) and leaks due to soil settlements (WLS=3.78) were ranked seventh and eighth in severity respectively followed by purposely damaged distribution lines and cause of loss, which has the least severity (WLS=2.29).

According to Figure 2 which presents graphically the economic analysis of the program, the best investment would be in reducing the NRW level up to $21.5 \%$. 


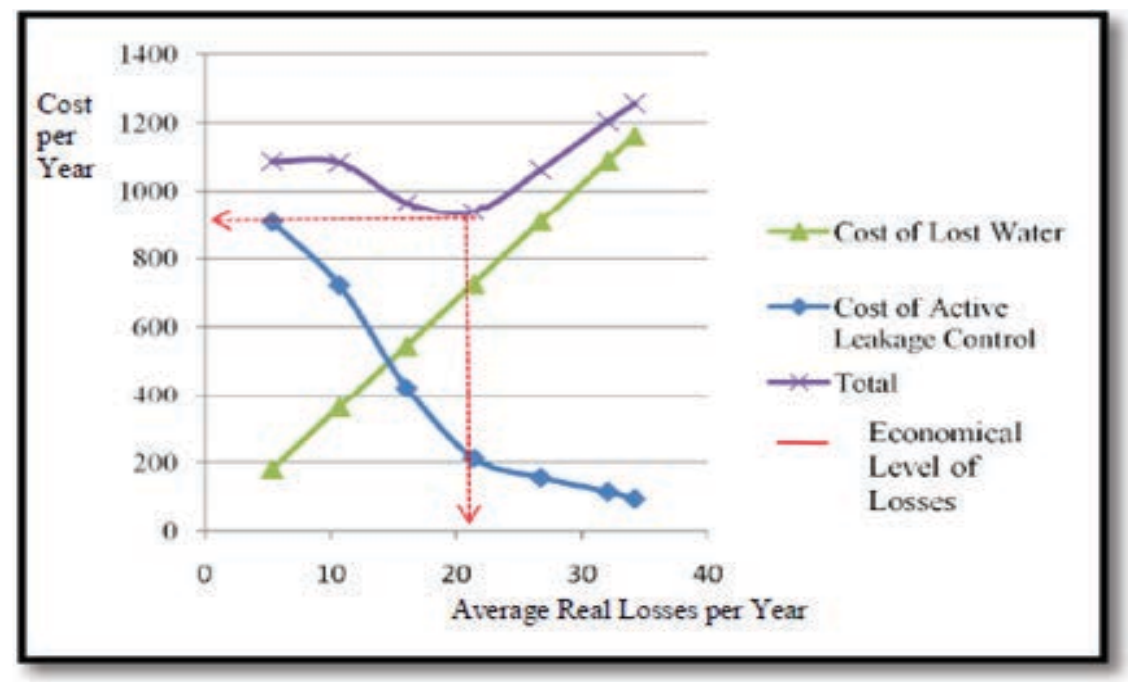

Figure 2 - Economic analysis of the active leakage control program

\subsection{Economic Analysis of Reducing Illegal Water Connections}

Table 5 illustrates the number of illegal water connections detected within the last five years, costs of their detections and the revenue recovered as loss of revenue due to illegal usage.

Table 5 - Cost of illegal connections and the revenue lost due to illegal connections

\begin{tabular}{|l|l|l|l|}
\hline Year & $\begin{array}{l}\text { Number of } \\
\text { illegal } \\
\text { connections }\end{array}$ & $\begin{array}{l}\text { Cost of } \\
\text { detection } \\
\text { in Rs }\end{array}$ & $\begin{array}{l}\text { Revenue } \\
\text { recovered in } \\
\text { Rs }\end{array}$ \\
\hline 2010 & 1669 & $11.2 \mathrm{~m}$ & $22.49 \mathrm{~m}$ \\
\hline 2011 & 1391 & $16.8 \mathrm{~m}$ & $53.50 \mathrm{~m}$ \\
\hline 2012 & 1167 & $13.8 \mathrm{~m}$ & $42.78 \mathrm{~m}$ \\
\hline 2013 & 1661 & $12.3 \mathrm{~m}$ & $28.74 \mathrm{~m}$ \\
\hline 2014 & 959 & $13.2 \mathrm{~m}$ & $22.94 \mathrm{~m}$ \\
\hline
\end{tabular}

Source - Reports on Illegal connections in NWS\&DB (2015)

According to the participants of the preliminary interviews, all water connections in the Colombo area had been unmetered in 1982. Table 3 indicates that in the year 2010, 1669 illegal connections have been identified at the expense of Rs. $11.2 \mathrm{~m}$ to the NWS\&DB while Rs. $22.49 \mathrm{~m}$ has been recovered as revenue. Moreover, the number of illegal water connections detected in the years 2011, 2012, 2013 and 2014 had been 1391, 1167, 1661 and 959 respectively. The number of illegal detections can be expected to decrease with time. NWS\&DB has implemented several projects for installation of water meters after it was revealed that there are a large number of unmetered connections. With the implementation of these projects, the detection of illegal connections has got more streamlined and the number of illegal connections has begun to decrease. Because of legal implications, the tendency on the part of consumers to obtain illegal connections has also decreased. The net result has been a decrease in the number of illegal connections detected. The information tabulated in Table 5 is presented graphically in Figure 3, to identify the economic benefits on investing in illegal water connection detection programs. A considerable amount of revenue has been recovered from consumers who used illegal water connections. The economy of detection has always been less than the cost of detection. indicating that investments could still be made in the detection of illegal connections which will ultimately benefit the utility.

\subsection{Economic Analysis of Reducing Administrative Losses}

Administrative losses also contribute around $4 \%$ of the water supply to NRW. Therefore, it is essential to focus on water pressure management, water meter management, meter reader malpractices and data entry errors to reduce the NRW levels. 


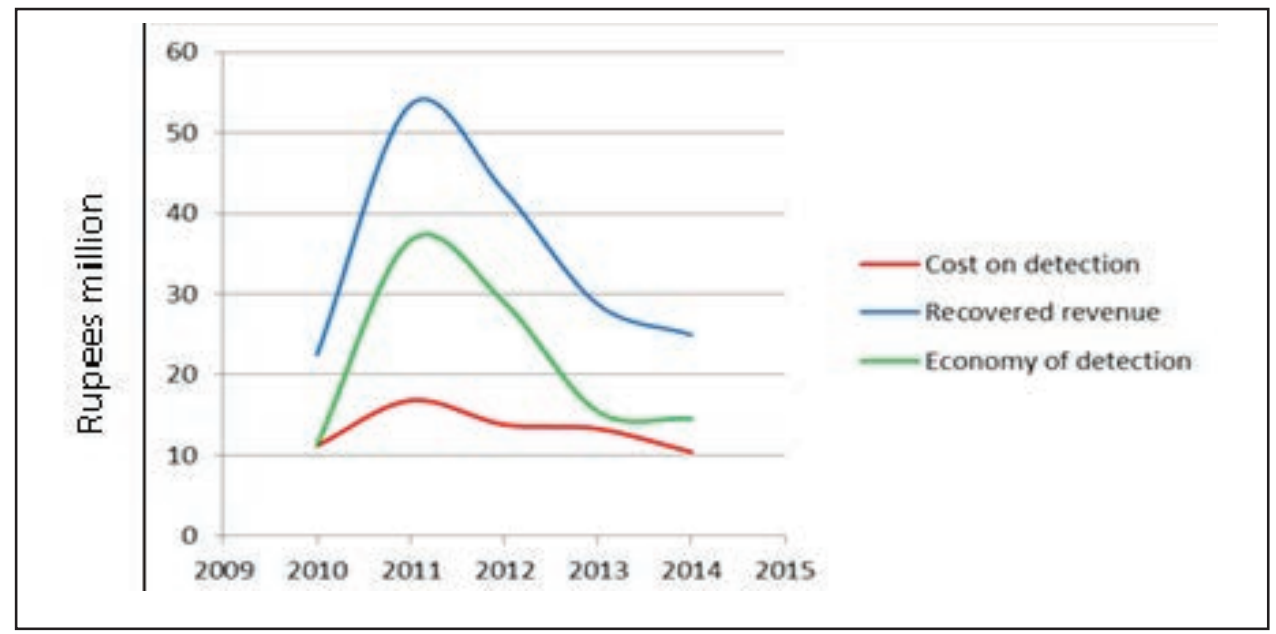

Figure 3 - Economic analysis of illegal water detections

Investments could be made in pressure management and meter management under active leakage control programs. Efficiency of NRW administration can be low due to "malpractices of meter readers" and "errors in data entry". These unwanted practices and errors can be prevented at no additional cost as the staff are already being paid to carry out these tasks. If necessary, qualified staff can be employed additionally and the current staff could be motivated. In addition, training and educating of the staff will also be very important.

\subsection{Cost effective Non-Revenue Water Management Model}

It is challenging to detect water losses in distribution systems. If all of the losses that occur in the distribution lines could be traced and detected, thereafter for quite some time there would not be any water loss, a situation quite unlikely. Therefore, it is essential to plan for the prevention of water losses beginning from the planning and design stage of a water distribution project. This will make it possible to completely do away with some of the subcauses of NRW such as the losses due to use of poor quality materials and workmanship.

Based on the findings of the research, the cost effective NRW model shown in Figure 4 was developed. Investments in active leakage control (ALC) can be stopped when leaks get reduced to $21.5 \%$. By getting the administrative staff to strictly attend to their duties stated in their job specifications, the issues that contribute to NRW due to administrative errors could be addressed. Several creative agendas could be prepared to track administrative errors which will be effective in reducing NRW levels.
Hence, it is recommended to invest in a total pipe relay project as a long term strategy to remove the existing leaks if the distribution system is very old or the amount of NRW is very high due to illegal connections. Furthermore, the distribution systems should have the latest technologies such as welldefined DMAs (District Metered Areas) and GPS (Global Positioning System) meter monitoring. Infrastructure automation solutions such as SCADA (Supervisory Control and Data Acquisition) systems can be implemented in the water distribution network.

It is also recommended to delegate the responsibility for water distribution to private institutions. The existing rules in Sri Lanka on water thefts have to be made more stringent to allow for higher penalties.

\section{Conclusions}

NRW has caused a significant reduction in the revenue earned by the utility in Sri Lanka by selling treated water. The severity of each type of water loss identified was evaluated first to determine the critical factors that affect it. By passing of water connections, deteriorated pipe lines and deformation of pipes caused by hard roots of trees were identified as the most critical factors. Subsequently, an economic analysis of active leakage control programs, reduction of illegal water connections and reduction of administrative losses was carried out to identify the cost effectiveness of each investment. It was concluded that investments have to be made on reducing NRW up to the level at which it is economical. According to the cost effective model developed, the causes of NRW have to be individually addressed and considered in long-term planning. Mitigation of water losses under four different categories was also 


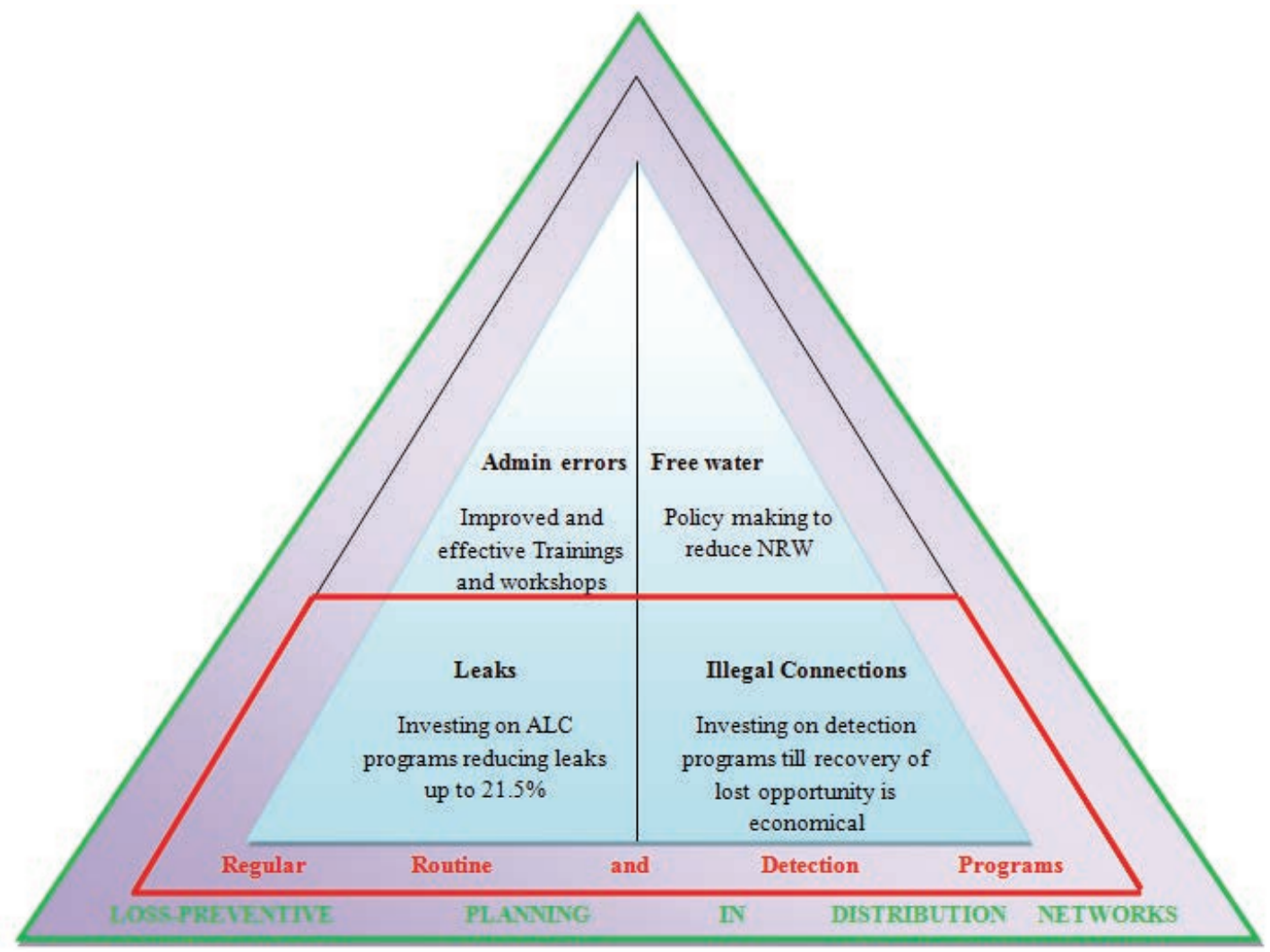

Figure 4 - Cost effective NRW management system

evaluated. A cost effective NRW management model suitable to Sri Lanka was finally simulated after studying the findings of the data analysis. It is recommended that the distribution system in Sri Lanka be equipped with the latest technologies to enable monitoring and controlling of water tanks as well as consumer units.

Well-defined District Meter Area Programs and monitoring of each consumer connection using GPS are also proposed to prevent meter reader malpractices. More importantly, the SCADA system which is already available in water treatment plants can be installed in the water distribution network as well, to reduce the amount of non-revenue water wasted in the potable water lines in Sri Lanka.

\section{Acknowledgement}

Authors wish to acknowledge all the officers of the National Water Supply and Drainage Board who extended unstinted cooperation to make this research a success.

\section{References}

1. Saunders, P., Lewis, P. and Thornhill, A., "Research Methods for Business Students", 5th ed., Edinburgh Gate, Harlow: Pearson Education Limited, 2009.

2. Stenbacka, C., "Qualitative Research Requires Quality Concepts of its own, Management Decision", Emerald Group Publishing Limited, 2001.

3. Ameyaw, E. E., \& Chan, A. P. C., "Evaluation and Ranking of Risk Factors in Public-Private Partnership Water Supply Projects in Developing Countries Using Fuzzy Synthetic Evaluation Approach", Expert Systems with Applications, Vol. 42, No. 12, 2015, pp. 5102-5116.

4. Bimpas, M., Amditis, A., \& Uzunoglu, N., "Detection of Water Leaks in Supply Pipes Using Continuous Wave Sensor Operating at $2.45 \mathrm{GHz}^{\prime}$, Journal of Applied Geophysics, Vol. 70, No. 3, 2010, pp. 226-236.

5. Cronbach, L. J., "Coefficient Alpha and the Internal Structure of Tests", Psychometrika, Vol. 16, 1951, pp. 97-334.

6. Du Toit, J. L., \& Mouton, J., “A Typology of Designs for Social Research in the Built Environment", International Journal of Social Research Methodology, Vol. 16, No. 2, 2013, pp. 125-139. 
7. Fang, D, Li M, Fong PS-W, \& Shen L., “Risks in Chinese Construction Market-Contractors' Perspective", J Constr Eng Manage, Vol. 130, 2004, pp. 853-861.

8. Farias, C., \& Farias, G., "Cycles of Poverty and Consumption: The Sustainability Dilemma. Competitiveness Review: An International Business Journal, Vol. 20, No. 3, 2010, pp. 248 - 257.

9. Gumbo, B., and Van der Zaag, P., "Water Losses and the Political Constraints to Demand Management: the Case of the City of Mutare, Zimbabwe", Physics and Chemistry of the Earth, Parts A/B/C, Vol. 27, No. 11-22, 2002, pp. 805-813.

10. Habiba, U., Abedin, M. A., \& Shaw, R., "Defining Water Insecurity. Water Insecurity: A Social Dilemma", Community, Environment and Disaster Risk Management, Vol. 13, 2014, pp. 3-20

11. Kang, D., Appellant, Button \& Gaga., "Real-time Optimal Control of Water Distribution Systems", Procedia Engineering, Vol. 70, 2014, pp. 917-923.

12. Kingdom, B., Liemberger, R., \& Marin, P., "The Challenge Of Reducing Non-Revenue Water (NRW) in Developing Countries", Water Supply and Sanitation Board Discussion Paper Series, Vol. 8, No. 1, 2006.

13. Knobloch, A., Guth, N., \& Klingel, P., "Automated Water Balance Calculation for Water Distribution Systems", Procedia Engineering, Vol. 89, 2014, pp. 428-436.

14. Lenzi, C., Bragalli, C., Bolognesi, A., \& Fortini, M., "Infrastructure Leakage Index Assessment in Large Water Systems", Procedia Engineering, Vol. 70, 2014, pp. 1017-1026.

15. McKenzie, R., \& Seago, C., "Assessment of Real Losses in Potable Water Distribution Systems: Some Recent Developments", Water Science and Technology, Vol. 5, No. 1, 2005, pp. 33-40.

16. Mohsen T., \& Reg D., "Making Sense of Cronbach's alpha", Int J Med Educ. Vol. 2, 2011, pp. 53-55.

17. Mutikanga, H. E., Sharma, S. K., \& Vairavamoorthy, K., "Water Loss Management in Developing Countries", Journal AWWA, Vol. 32, No. 1, 2009, pp. 1-12.

18. Perera, B. A. K. S., Rameezdeen, R., Chileshe, N., \& Hosseini, M. R., "Enhancing the Effectiveness of Risk Management Practices in Sri Lankan Road Construction Projects: A Delphi Approach", International Journal of Construction management, Vol. 14, No. 1, 2014.
19. Sanderson, M. L., "Domestic Water Metering Technology", Flow Measurement and Instrumentation, Vol. 5, No. 2, 1994, pp. 107-113.

20. Sankar, G. S., Mohan Kumar, S., Narasimhan, S., Narasimhan, S., \& Murty Bhallamudi, S., "Optimal Control of Water Distribution Networks with Storage Facilities", Journal of Process Control, 2015.

21. Scibetta, M., Boano, F., Revelli, R., and Ridolfi, L., "Community Detection as a Tool for District Metered Areas Identification", Procedia Engineering, Vol. 70, No.2014, pp. 1518-1523.

22. Signori, S., and Bodino, G. A., "Water Management and Accounting: Remarks and New Insights from an Accountability Perspective", Accounting and Control for Sustainability (Studies in Managerial and Financial Accounting), Vol. 26, No. 2013, pp. 115 - 161.

23. Sun Y., Fang D., Wang, S., Dai, M., Lv X., "Safety Risk Identification and Assessment for Beijing Olympic Venues construction", J Manage Eng, Vol. 24, 2008, pp. 40-47.

24. Zheng, F., and Zecchin, A., An Efficient Decomposition and Dual-Stage Multi-Objective Optimization Method for Water Distribution Systems with Multiple Supply Sources. Environmental Modelling and Software, Vol. 55, 2014, pp. 143-155.

25. Zheng, F., Zecchin, A. C., and Simpson, A. R., "Investigating the Run-Time Searching Behavior of the Differential Evolution Algorithm Applied to Water Distribution System Optimization", Environmental Modelling and Software, Vol. 69, 2015, pp. 292-307.

26. Zou PX, Zhang G, Wang J., "Understanding the Key Risks in Construction Projects in China", International Journal of Project Management, Vol. 25, 2007, pp. 601-614.

27. Gliem, J. A., \& Kowalski., "Calculating, Interpreting, And Reporting Cronbach's Alpha Reliability Coefficient For Likert-Type Scales, 2003 Midwest Research to Practice Conference in Adult, Continuing, and Community Education", 2003, pp 82-88.

28. Santos, J. R. A., Lippke, L., \& Pope, P. "PROC FACTOR: A Tool for Extracting Hidden Gems from a Mountain of Variables", Proceedings of the 23rd Annual SAS Users Group International Conference. Cary, NC: SAS Institute Inc, 1998.

29. Sivakumaran, S., Perera, B. A. K. S and Perera, K. T. P. K., "Construction Management as a Suitable Procurement Method for Hotel Building Construction in Sri Lanka", In Proceedings of the 19th Pacific Association of 
Quantity Surveyors Congress 2015, Japan, Pacific Association of Quantity Surveyors, 2015.

30. Chandrathilaka, R., \& Fernando, S., “Guidelines: Green Building Council of Sri Lanka", May, 2011, http://www.srilankagbc.org/ape/ green_design_guidelines.pdf, Visited $05^{\text {th }}$ May 2015.

31. Eguavoen, R., \& Youkhana, E., “Small Towns Face Big Challenges: The management of piped systems after the water sector reform (Report No. 26)", Bonn: University of Bon, Department of Political and Cultural Change, 2008.

32. Frauendorfer, R., \& Liemberger, R., "The Issues and Challenges of Reducing Non-Revenue Water. Philippines: Asian Development Bank", 2010, http:/ / hdl.handle.net/11540/1003, Visited 10th May 2015.
33. Kamarazaly, M. A., "A Mature Profession of Quantity Surveying in Sri Lanka, (Unpublished MPhil thesis), University of Messay, Wellington, 2007.

34. Tomoko, T., "Publications: JICA", 2009, April, http://www2.jica.go.jp/en/evaluation/pdf/20 08_SL-P49_4.pdf, Visited 29th May 2015. 